\title{
IDUA wt Allele
}

National Cancer Institute

\section{Source}

National Cancer Institute. IDUA wt Allele. NCI Thesaurus. Code C115254.

Human IDUA wild-type allele is located in the vicinity of $4 \mathrm{p} 16.3$ and is approximately $18 \mathrm{~kb}$ in length. This allele, which encodes alpha-L-iduronidase protein, is involved in the metabolism of glycosaminoglycans. Mutation of the gene is associated with mucopolysaccharidosis type 1 . 